\title{
"Reestruturação Produtiva, Qualificação, Requalificação e Desemprego: \\ Percepção e Sofrimento do Trabalhador"
}

Com a expansão capitalista, a busca por mais produtividade e mais lucratividade se acentuou, favorecenco assim, o avanço tecnológico e a concentração de capitais. Essas mudanças tiveram grande impacto sobre o mundo do trabalho, pois, resultou na diminuição de postos de trabalho. Assim este trabalho teve como objetivo verificar, através do discurso do trabalhador, como essas mudanças são percebidas por ele. $O$ desemprego cresce em todas as faixas de escolaridade. Entretanto, o discurso ideológico prega que o desemprego é causado pela falta de qualificaçāo (formal ou técnica) do trabalhador. Sob esse controle ideológico, o trabalhador responsabiliza-se por năo ter estudado o suficiente e, diante da situação de desemprego sofre duas vezes: uma, pelas privações materiais e, outra, por colocar-se responsável por seu próprio desemprego.

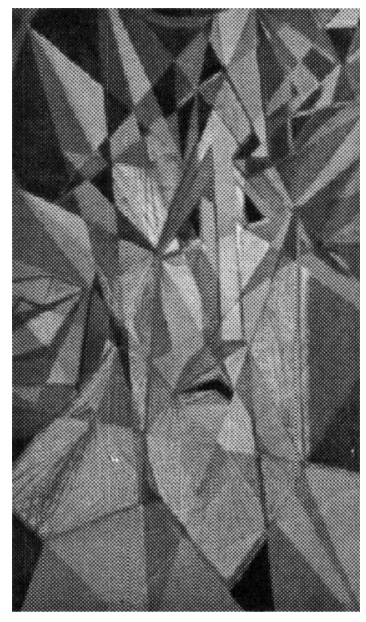

Maristela Miranda Barbara Psicóloga Clínica

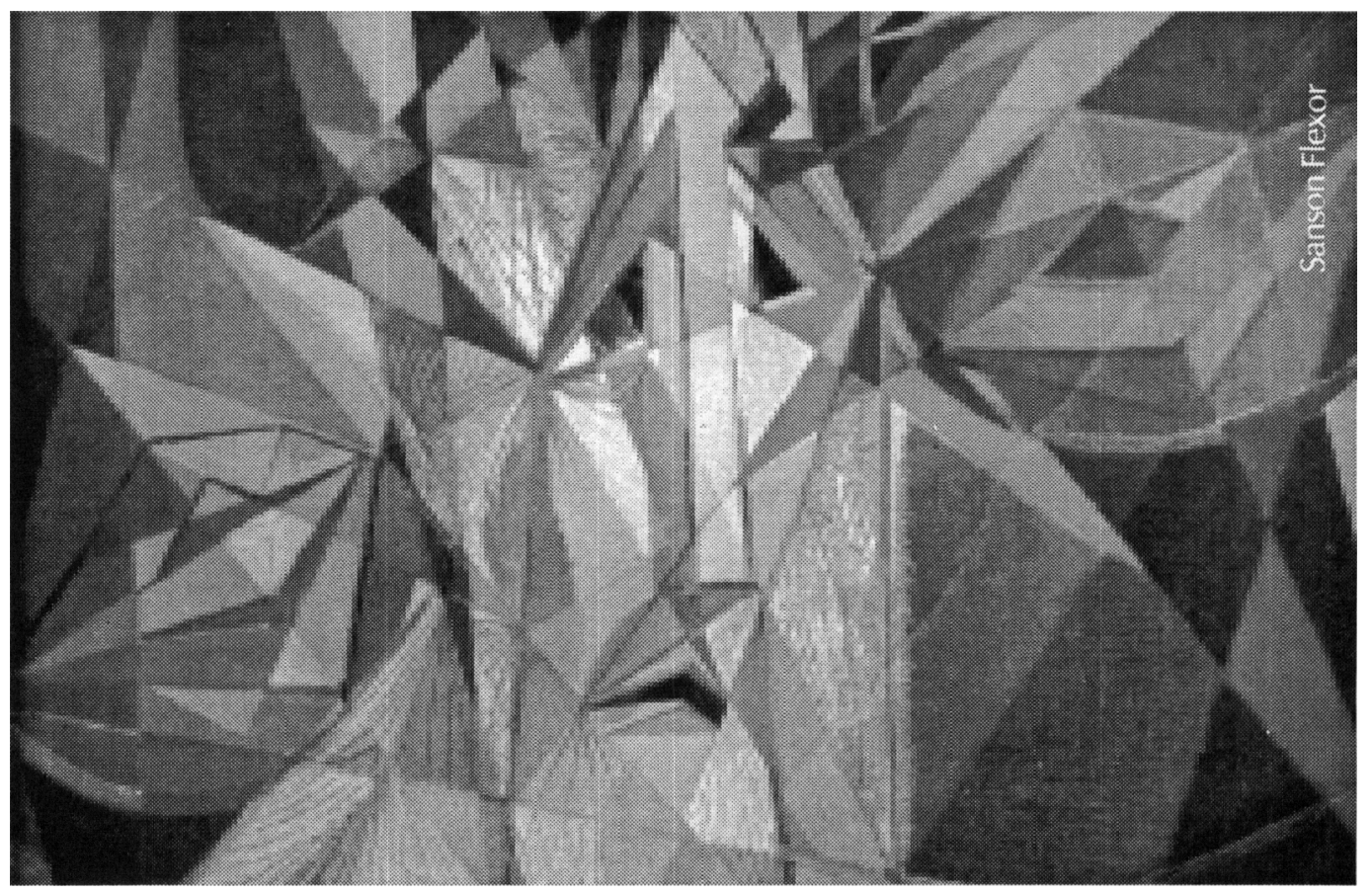

"O eterno recomeçar da miséria, o trabalho pesado, o destino de rebanho que dá a lã e é degolado, todas essas desgraças desapareciam, como que varridas por um raio do sol, e, num desabar feérico, a justiça descia do céu. Já que Deus estava morto, a justiça asseguraria a felicidade humana, fazendo reinar a igualdade e a fraternidade. Uma sociedade nova surgiria em um dia, como nos sonhos: uma cidade imensa, esplêndida como uma miragem, onde cada cidadão viveria do seu trabalho e teria o seu quinhão nas alegrias comuns" (Zola, 1881, p.177). 
Este trabalho tem como objetivo verificar, através do discurso do trabalhador, como as novas formas de produção que estão sendo adotadas na indústria, e mais especificamente a requalificação, são percebidas por ele.

Primeiramente faz-se necessário verificar que mudanças são estas que estão ocorrendo no processo produtivo na visão de vários autores contemporâneos.

\section{Sistema de Produção}

A significativa mudança que vem ocorrendo no sistema de produção mundial trouxe grandes modificaçōes ao mundo do trabalho, segundo alguns autores (Antunes, (1997); Mattoso, (1995)); estas mudanças são tão significativas que se pode falar em metamorfose do mundo do trabalho, devido a restruturação das formas de produção.

Para esses mesmos autores, restruturação produtiva é, principalmente, a mudança do sistema americano de produçāo fordista/ taylorista para o modelo japonês toyotista. Ambos tiveram seus berços nas indústrias automobilísticas.

\section{Fordismo/Taylorismo}

O sistema de produção fordista foi criado para atender as necessidades de um mercado consumidor em demanda crescente; a produção era em série e pouco variada, como forma de reduzir custos, tal sistema só pôde realizar-se em grande escala através da esteira rolante criada por Henry Ford que, com seu invento, elevou ao máximo o aproveitamento da técnica de decomposição do processo de produção, criada pelo engenheiro americano Taylor, na qual cada trabalhador fazia apenas uma pequena parte do todo: "Com isto podiam ser eliminados do processo de trabalho industrial os últimos restos de competência artesanal" (Kurz, 1993, p.236).

Essa forma de produção foi adotada por outros setores da indústria. "Assim tornou-se possível, para muito além da indústria automobilística, a produçăo em massa em muitos setores. Somente após a segunda Guerra Mundial, impôs-se o fordismo universalmente. As novas indústrias de produção em massa nāo apenas se tornaram o centro de uma acumulação de capital sem par, mas também o de um modelo social" (Kurz, 1993, p.237). Segundo o mesmo autor, esse modelo também teve seu reflexo no modo de viver das pessoas, marcado pela uniformidade.

Este modelo de produção predominóu até início dos anos 80 , quando começou a declinar, sendo então substituído por outra forma de produção, o então chamado modelo japonês ou toyotismo.

Toyotismo

O modelo japonês, segundo Antunes (1997), vem trazendo maior impacto não só pela revolução tecnológica que operou na indústria japonesa, mas também pela sua potencialidade de propagação, que hoje atinge uma escala mundial, demonstrando assim possuir traços universais da economia capitalista.

\section{O Advento do Toyotismo, para Coriat (1994), Passa por Quatro Fases:}

$1^{\circ}$. Implantação no setor automobilístico das inovações técnico-organizacionais herdadas da experiência têxtil . "...consistindo em confiar ao mesmo operário a conduçăo e a gestão simultâneas de várias má-quinas" (Coriat, 1994, p.37). Isto acarretou uma modificação na espacialidade das fábricas e no modo de exploração da força de trabalho. pois um mesmo trabalhador passou a ser responsável por várias máquinas ao mesmo tempo, surgindo assim a chamada polivalência do trabalhador.

$2^{\circ}$. Nos anos de 1949 e 1950 , a Toyota passava por uma crise. "A empresa se acha acuada, de fato, tendo que encontrar meios de aumentar vigorosamente sua oferta de produtos sem poder recorrer a admissão de novos empregados"(Coriat, 1994, p.38). A empresa havia acabado de demitir mais de 1.600 empregados depois de uma greve que durou dois meses. "...A única via aberta era a da racionalização do trabalho apoiada no maior rendimento possivel do trabalho vivo, centrado não na repetição de tarefas mas na sua 'ampliação' em fórmulas como aquelas já experimentadas no setor têxtil." (Coriat , 1994, p.55)
Uma sociedade nova surgitia em um dia, como nos sonhos: uma cidode imensa, esplêndida comouma miragem, ande cada cidadóo viveria do seu trabalho e teria o seu quinhōonas alegrias comuns" [Zola, 1881, p.177]. 
$3^{\circ}$. A importação da técnica de gestão de estoques dos supermercados norteamericanos para a indústria automobilística sistema que ficou conhecido nesta adaptação como Kan-Ban - caracterizando-se por : trabalhar com estoque mínimo e produzir no menor tempo possivel-just in time -. O kanban é um dos pilares de todo este sistema "O ideal seria produzir exatamente aquilo que é necessário e fazê-lo no tempo exatamente necessário" (Coriat, 1994, p.38).

$4^{\circ}$. Extensão do método Kan-Ban aos subcontratantes: "De 1962 ao pós 1973, o esforço é dirigido aos subcontratantes e aos fornecedores ao mesmo tempo em que, no interior da empresa, o sistema conhece vários desenvolvimentos e aperfeiçoamentos"(Coriat, 1994, p.39).

Comparando com o método fordista, a diferença mais significativa é que no sistema toyotista há uma inversāo das regras de produçāo. No fordismo, a produção direciona o consumo e no toyotismo é feito o contrário,

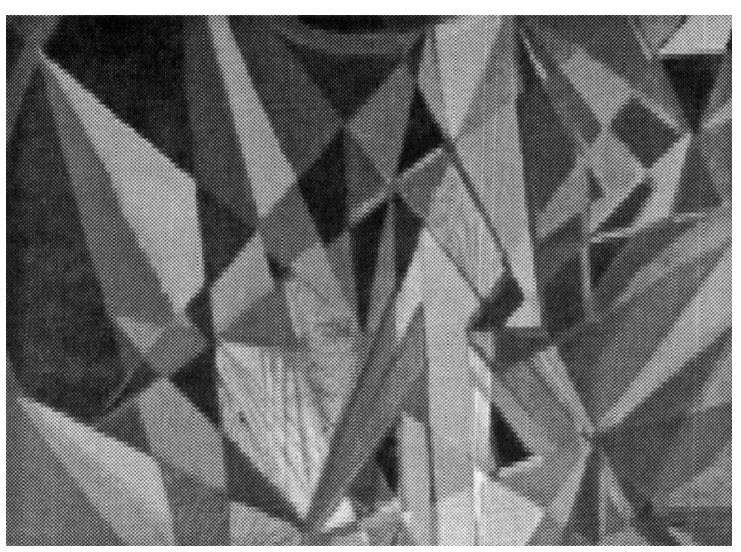

o ponto de partida é das encomendas para a fábrica, isto é, só se produz o que já foi vendido; esse processo, segundo Ohno, tem como objetivo a diminuição de pessoal "o conceito de economia é indissociável da busca de redução de efetivos e da redução dos custos" (Coriat, 1994, p.33).

\section{Mundo do trabalho}

Com a expansão capitalista, através do sistema de produção toyotista, a busca constante por mais produtividade e mais lucratividade se acentuou, favorecendo assim o avanço tecnológico e a concentração de capital. "...Esta profunda transformação do capitalismo mundial redefiniu os parâmetros produtivos, tecnológicos, de concentraçăo de capitais, de globalização e instabilidade financeira ." (Mattoso, 1995, p.142)

No Brasil, estas transformaçōes ocorreram mais tardiamente, em relaçâo aos principais países do mundo, tornando-se mais significativas a partir da década de 90.0 modo de desenvolvimento do Brasil passou, nesta década, de um estilo de industrialização protegida para o de uma economia aberta e competitiva. A inserção da economia brasileira no processo de globalização gerou significativas alteraçôes sobre os fluxos de comércio e de capitais, sobre a base tecnológica, gerencial e organizacional das empresas e, conseqüentemente, sobre as relaçōes de trabalho, pois, a produção passou a visar o melhor aproveitamento possivel do tempo de produçāo.

Segundo Antunes (1997) e Mattoso (1995), todas estas mudanças no mundo do trabalho caracterizam-se basicamente pela: diminuição dos ciclos de produçâo, mudança na divisảo do trabalho dentro das empresas, consolidação das tecnologias da computaçāo e da informática, polivalência e treinamento dos trabalhadores como requisitos essenciais aos novos processos produtivos.

Todos esses fatores tiveram um grande impacto sobre o mundo do trabalho, pois o aumento de produtividade tăo desejado pelas empresas aliado à diminuição do tempo de trabalho por unidade produzida, trouxe como conseqüência a diminuição de muitos postos de trabalho e, muitos trabalhadores, alijados do mercado de trabalho formal, são levados a aceitar empregos de baixa qualidade, ou a buscar sua subsistência como autônomos ou assalariados sem carteira.

Como resultado dessa modernização e busca por mais produtividade ao menor custo, as empresas passaram a buscar, ao mesmo tempo, cortes de pessoal e elevação da jornada de trabalho, agravando assim as condiçōes do mercado de trabalho no Brasil. 
Além do crescimento do desemprego, está ocorrendo uma ampliação da economia informal, mostrando que as melhorias técnicas diminuem os empregos em vez de criá-los. "Nos anos 90, enquanto a produtividade ampliou-se consideravelmente, o emprego industrial caiu mais intensamente" (Mattoso, 1996, p.47). Dificilmente pode-se encontrar um único setor industrial em que o número de empregados não tenha tendência a contrairse. Segundo Antunes (1997), nos dias atuais é impossivel ignorar o extraordinário efeito destas metamorfoses sobre o mundo do trabalho. A contínua redução industrial e o crescimento menor dos serviços têm ampliado o desemprego e a insegurança no trabalho, pois, com a redução de postos de trabalho, a qualidade desses empregos afastase dos padrões desejáveis, aumentando, assim, o trabalho precário, com a conseqüente ampliaçáo das desigualdades sociais, da pobreza e da exclusão. Parte do aumento do desemprego deve-se à reestruturação tecnológica e à adoção de novas formas de organização do trabalho que as empresas vêm praticando com o objetivo de reduzir custos e de aumentar a competividade dentro de uma economia aberta e globalizada .

\section{O Trabalhador}

Todas essas mudanças no mundo do trabalho tiveram como objetivo aumentar a produtividade; assim, pela primeira vez na história houve aumento na produçăo sem que houvesse um correspondente aumento dos empregos . Para Kurz (1997), a māo-de-obra barata, com a qual países como o Brasil contavam desenvolver uma indústria moderna, perdeu importância e já não há compradores.

"Depois de lutar contra a exploração capitalista, os trabalhadores deverảo se debater contra a falta desta ..." "Kurz, 1993, p. 17). Como salienta Forrester: "Para além da exploraçāo dos homens, havia algo ainda pior: a ausência de qualquer exploração" (Forrester, 1997, p. 16).

No sistema atual de produção, o trabalhador é, na grande maioria das vezes, simplesmente um executor de qualquer serviço que qualquer um poderia fazer. Não importa se o trabalho é intelectual ou braçal, com a implantaçâo da informática e robótica, a maioria dos trabalhos são pré-determinados, restando pouco espaço para o exercício da inteligência e da criatividade. A tarefa do trabalhador é simplesmente operar máquinas que ditam o ritmo, ou suprir os computadores com os dados que estes exigem.

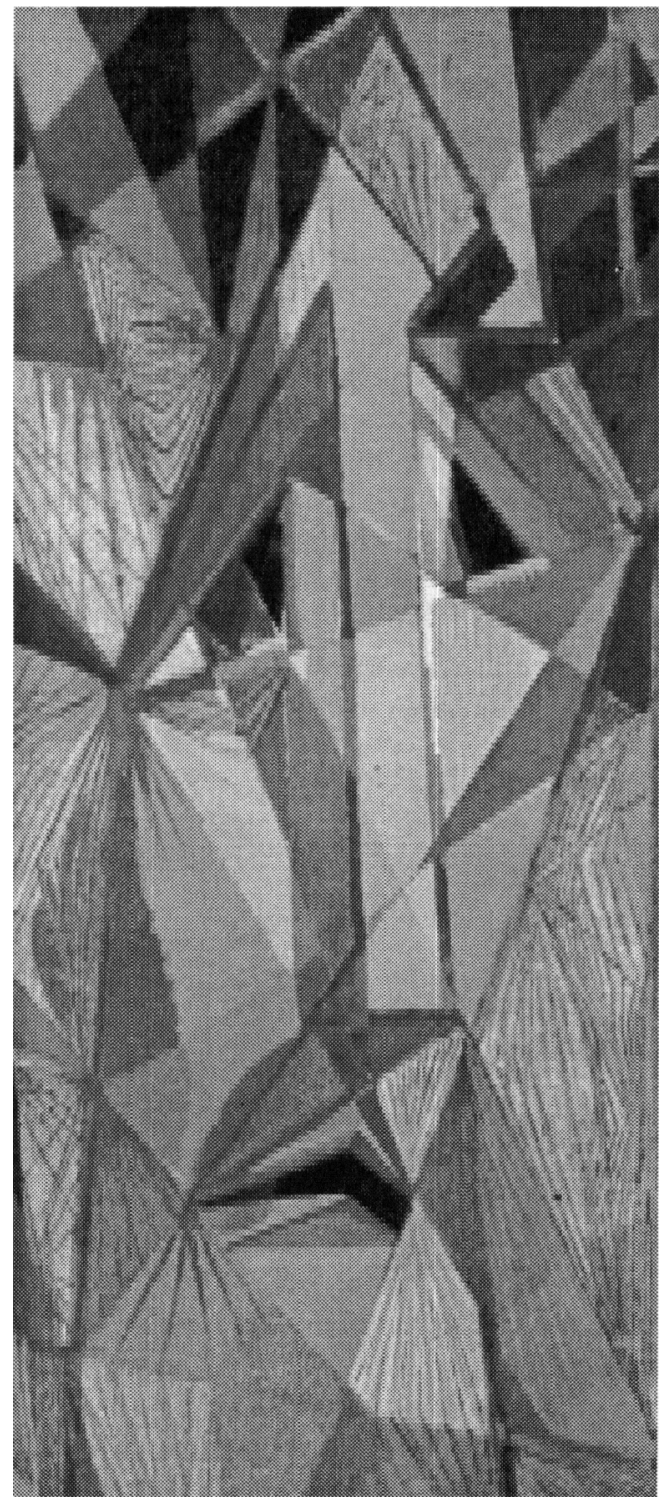

O discurso oficial prega que a alocação ou recolocação dos trabalhadores só será viável com uma correspondente qualificação ou requalificação dos mesmos e, cada vez mais, a responsabilidade pelo aperfeiçoa-mento é atribuída ao próprio trabalhador. 
O trabalhador, pretendendo atender às novas exigências do mercado, busca qualificar-se; porém, muitas vezes, desprovido de senso crítico e sem qualquer orientação, pode acabar como vítima do comércio travestido de escolas de especialização (curso de informática, inglês "fácil" e até mesmo pósgraduação em universidades de qualidade duvidosa) , o que, segundo Corz (1987), pouca utilidade vai ter, "... aprendem ofícios que jamais exercem de forma regular, realizam estudos para os quais não há mercado nem utilidade prática possível" p.90).

Essa busca por especialização é incentivada pela idéia de que o novo trabalhador deve ser polivalente e mais qualificado. No entanto, quase sempre, esta pretendida polivalência não passa de uma ampliaçăo de tarefas. A ampliaçăo pode estar se referindo à agregação de tarefas do mesmo tipo (operação de várias máquinas ao mesmo tempo) ou de baixa especialização (conservação e inspeção elementar), o que equivaleria, então, a um sistema de multitarefas. Ocorrem ainda, segundo o DIEESE (1996), casos em que empresas

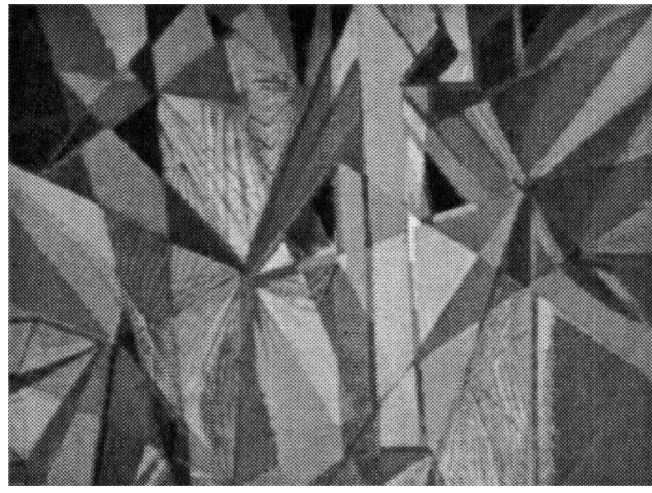

demitem os operadores das máquinas e os substituem por mecânicos de manutenção que assim, no caso de quebra do equipamento, prontamente o reparam. $O$ que acontece, então, é a realocação de trabalhadores, com a desculpa de que é necessário outro perfil ocupacional, trazendo desemprego e dificuldade de encontrar trabalho para aqueles demitidos com qualificação considerada insuficiente, inadequada ou ultrapassada; com o contingente de trabalhadores na reserva cada vez maior, as empresas podem "dar-se ao luxo" de exigir trabalhadores com qualificaçāo muito acima do que seria necessário para um bom desempenho da funçāo, porque a maioria das tarefas sāo de fácil execução. "A maioria das funçōes típicas da fábrica exigem apenas uma formação incompleta do primeiro grau em aritmética, soletração, leitura, escrever e falar" (Braverman, 1974, p.371).

A reorganização estrutural tecnológica das empresas em busca de produtividade e competitividade implica altos níveis de desemprego, o que gera insegurança para aqueles que estāo empregados, cada um tenta a todo custo manter-se no emprego, procurando assim, saídas individuais e não mais coletivas, processo que acaba acarretando uma desorganizaçăo das entidades coletivas dos trabalhadores. Segundo Antunes (1997), é comum, hoje, um clima de adversidade e hostilidade contra $o$ sindicalismo. $O$ sindicato antes empenhado na melhoria das condiçōes de trabalho, com o aumento do desemprego, passa a atuar preferencialmente visando a manutenção e a ampliaçāo dos empregos, enfraquecendo o seu poder de ação, e sofrendo uma crescente dessindicalização dos trabalhadores, o que, aliás, é bastante encorajado pelas empresas.

" Tudo isto dificulta ainda mais as possibilidades do desenvolvimento $e$ consolidação de uma consciência de classe dos trabalhadores, fundada em um sentimento de pertencimento de classe... Uma crescente individualização das relaçōes de trabalho, deslocando o eixo das relaçōes entre capital e trabalho da esfera nacional para os ramos de atividade econômica e destes para o universo micro, para o local de trabalho, para a empresa $e_{r}$ dentro desta, para uma relação cada vez mais individualizada" (Antunes, 1997, pp.64-65).

\section{Qualificação e Requalificação: a Serviço de Quem?}

"A noção de que as condiçôes mutáveis do trabalho industrial e de escritório exigem uma população trabalhadora cada vez "mais instruída", "mais educada" eassim "superior", éuma afirmaçāoquase 
universalmente aceita na fala popular e acadêmica" (Braverman, 1987, p.359). Para este autor, os termos instrução e qualificação sāo vagos e imprecisos, embora atualmente sejam utilizados como se houvesse consenso na compreensāo do que significam.

$O$ termo qualificação sugere referir-se ao domínio de uma técnica apreendida após anos de treinamento. Braveman cita o exemplo do cocheiro que além de ter habilidade com os animais precisava entender de carroça, do manejo de ambos, etc. Entretanto, ainda que o tempo necessário para tornar-se um bom cocheiro seja muito maior do que o necessário para tornar-se motorista, este último é considerado mais qualificado. O tempo necessário para aprender operar uma máquina sofisticada pode ser umas poucas semanas e o operário será considerado mais qualificado que o motorista, isto porque a valorização da qualificação está sempre atrelada às necessidades momentâneas do mercado e não a apropriação de aigum ofício, e, mais ainda, nāo traz qualquer garantia de emprego para o trabalhador que consegue acompanhar tais evoluçōes : "...fiz curso para mexer em robô, eu estava bom mesmo, mais aí fizeram um sorteio e caiu eu."(pesquisa CUT/PUC, 1997, p.19)

Esta definição cambiante do que é estar qualificado faz com que o trabalhador fique sem referência sobre o que é preciso fazer para garantir seu lugar. "O que se deixa aos traballıadores é um conceito reinterpretado e dolorosamente inadequado de qualificação: uma habilidade específica, uma operaçāo limitada e repetitiva, 'a velocidade como qualificação', ...hoje o trabalhador é considerado como possuindo uma 'qualificação' se ele ou ela desempenham funçōes que exigem uns poucos dias ou semanas de preparo"(Braverman, 1987, p.375).

Segundo o Dieese (1996), é grande o número de empresas que estão deixando os estados mais industrializados, como Săo Paulo, e montando novas instalaçōes em regiōes menos desenvolvidas, principalmente no Nordeste, não em busca de trabalhadores mais qualificados, mas sim, entre outros fatores, em busca de mão-de- obra barata que, com pouco tempo de treinamento, habitua-se a operar suas sofisticadas máquinas.

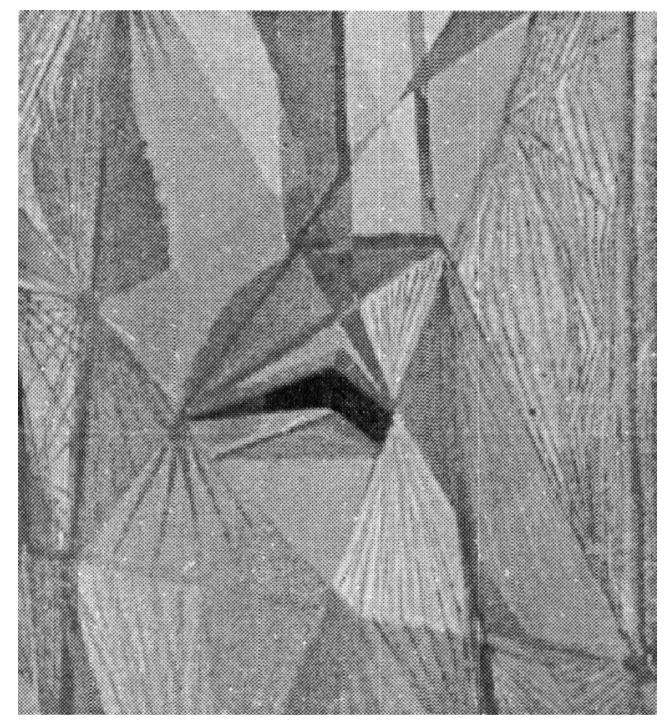

Em 1996, o crescimento do PiB da Região Nordeste, onde os índices de escolaridade são os mais baixos em relação a média nacional, foi de $4,1 \%$, enquanto que a média brasileira ficou em 2,9\% (Folha de São Paulo, 08.06.97, p.1-9). No Ceará, o crescimento foi ainda maior, $6,8 \%$, tal desempenho não pode ser atribuído à oferta de mão-de-obra altamente qualificada, mas sim barata, como admite o próprio Secretário do Trabalho daquele Estado, pois segundo ele, o modelo adotado não é baseado na superespecializaçāo e sim de mão-de-obra barata: "Queremos criar um capitalismo no estilo chinês, com cultura ocidental" ( $O$ Estado de São Pauio, 1997, p.D-1).

Desta forma, o termo qualificação pode estar mais a serviço da ideologia do que do trabalhador. A função ideológica da qualificação/requalificaçāo é servir para justificar, não só a exclusão, como o lugar que cada um ocupa na sociedade.

"Nesse contexto, é possivel perceber qual o trabalho específico do discurso ideológico: realizar a lógica do poder fazendo com que as divisōes e as diferenças apareçam como simples diversidade das condiçōes de vida de cada um" (Chaui, 1982, p.21). 
Segundo Chaui, é por não dizer tudo, e apenas mostrar um recorte da realidade, que o discurso ideológico é coerente e poderoso.

O aperfeiçoamento do trabalhador pode ser importante e necessário, pode ser condição primeira para qualquer trabalhador almejar disputar um posto de trabalho, mas não é por si só suficiente para acabar com o desemprego e a exclusão social. "Se fosse aperfeiçoada a educação de todos os trabalhadores na força de trabalho, mesmo assim alguns continuariam marginais, mas "sua marginalidade", então, apareceria associada com outras simples características isoladas"(Braverman, 1987, p.318). O trabalhador com a responsabilidade de qualificar-se e, ao mesmo tempo, sem referência do que seja qualificaçāo, quando demitido, ou diante da ameaça de demissão, sente-se culpado por nāo ter estudado mais, isto independentemente do quanto tenha estudado até então, e sofre. "São levados a se considerar indignos da sociedade, e sobretudo responsáveis pela sua própria situação, que julgam degradante (já que degrada ) e até censurável. Eles se acusam daquilo de que são vítimas" (Forrester, 1997, p.11).

A crítica que se faz à proposta de qualificação e requalificação tem em vista o uso ideológico destes termos que acabam servindo para justificar os problemas sociais. Segundo Pochmann (1997), atualmente o trabalhador para encontrar um emprego de qualidade $\mathrm{e}$ boa remuneração, necessita além da educaçāo, de outros elementos que não são dados por ela. A ênfase que é dada à educaçăo tem como propósito encobrir fatores da política macroeconómica. "... uma análise mais profunda sobre os determinantes da distribuição de renda no Brasil levariam, obviamente, a uma avaliação da política do Real, ... como o governo não tem condição de comprovar imediatamente que tendo educaçāo haverá emprego e melhor renda, joga para o futuro o problema, em vez de avaliar de fato quais são os fatores determinantes" (Pochmann, 1997, p.37).

A verdadeira democratizaçāo do conhecimento permitirá que cada um possa analisar de forma mais crítica e ampla seus determinantes históricos / sociais, chegando assim a um maior grau de consciência de si mesmo. Podemos dizer que cada um a partir daí, terá então, maior possibilidade de ação sobre o mundo e, assim, maior possibilidade de transformá-lo, pois, "Uma classe não pode existir na sociedade sem manifestar em algum grau uma consciência de si mesma como um grupo com problemas, interesses $\mathbf{e}$ expectativas comuns" (Braveman, 1987,p.36). Sendo assim, o acesso ao conhecimento é de fundamental importância, deste ponto de vista: " a valorização da escola como instrumento de apropriação do saber é o melhor serviço que se presta aos interesses populares, já que a própria escola pode contribuir para eliminar a seletividade social e torná-la democrática" (Libâneo, 1986, p.39).

\section{Aspectos Psicológicos}

Todas essas relaçōes de produção podem ser estudada como comportamento de indivíduos e, dentro da psicologia pode ser estudado de várias perspectivas, para o behaviorismo radical o comportamento é explicado como função da interação do organismo com o ambiente, esta interação modifica o indivíduo na medida em que ele vai sendo exposto às contingências ambientais. As experiências não são guardadas em um banco de dados para que a qualquer momento se possa delas dispor, tampouco sāo produtos de estados internos, como raiva ou amor.

Quando o comportamento do indivíduo é importante para a sociedade esta torna-o importante para o indivíduo, reforçando respostas verbais com respeito ao seu comportamento. Sendo assim, "Diferentes comunidades geram tipos e quantidades diferentes de auto conhecimento e diferentes maneiras de uma pessoa explicar-se a si mesma e aos outros " (Skinner, 1974, p.146).

Deve-se, então, buscar explicar o comportamento do trabalhador a partir das variáveis ambientais das quais é função. Quando o trabalhador assume a culpa do desemprego e da falta de qualificaçāo, pode estar respondendo à comunidade verbal que reforça este comportamento por ser importante para a sociedade, pois, assim, exime-se da responsabilidade pelos desequilibrios em sua forma de organização da produção e da distribuição de riquezas. 
Para que o trabalhador tenha consciência destes determinantes, é fundamental que ele aprenda a descrever as variáveis das quais seu comportamento é função.

"Estar conscientes é reagir ao próprio comportamento verbal. Um individuo consciente é capaz de descrever seu próprio comportamento, e isto só é possivel a partir de contingências promovidas pela comunidade verbal, isto é a consciência como produto social"(Tourino, 1995, p.15).

E mais ainda:

"Estamos conscientes do que fazemos, quando descrevemos a topografia de nosso comportamento. Estamos conscientes de por que o fazemos, quando descrevemos as variáveis relevantes, tais como aspectos importantes da ocasiāo ou o reforço" (Skinner, 1969, p.244).

Segundo Skinner, para investigar como uma situaçăo parece a uma pessoa, qual o significado tem para ela e como ela a interpreta "...precisamos examinar-lhe o comportamento em relação à situaçāo, inclusive suas descriçōes dela, e só podemos fazer isso em termos de suas histórias genéticas e ambientais" (Skinner, 1974, p.69), pois, quando uma pessoa é modificada pelas contingências de reforço, promovidas pela comunidade verbal, os estímulos passam a controlar tipos particulares de comportamento perceptivo, mas sempre produto do ambiente porque é a comunidade verbal que propicia contingências autodescritivas. Portanto o ambiente tem um papel importante no repertório comportamental das pessoas.

Isto se dá também no que diz respeito ao trabalhador, a sua percepção sobre a reestruturação produtiva e a qualificaçāo/ requalificaçāo, é passível de análise se for examinado o repertório comportamental que ele possui para descrever estas mudanças no mundo do trabalho.

Assim, este trabalho pretende, através da descriçăo do trabalhador verificar, como as novas formas de produção que estāo sendo adotadas na indústria, e mais especificamente a requalificação, sâo percebidas por ele.

\section{Método}

\section{Fontes}

Como este trabalho visa o enfoque do trabalhador, foi feito um levantamento, junto a algumas entidades vinculadas aos interesses do trabalhador (DIEESE, Sindicato dos Bancários, CUT, Programa Integrar PUC/ CUT e Unitrabalho), a fim de verificar que documentos relacionados ao tema de análise estavam disponiveis. Confirmada a existência de pesquisas que poderiam contribuir para os propósitos deste trabalho, optou-se pela

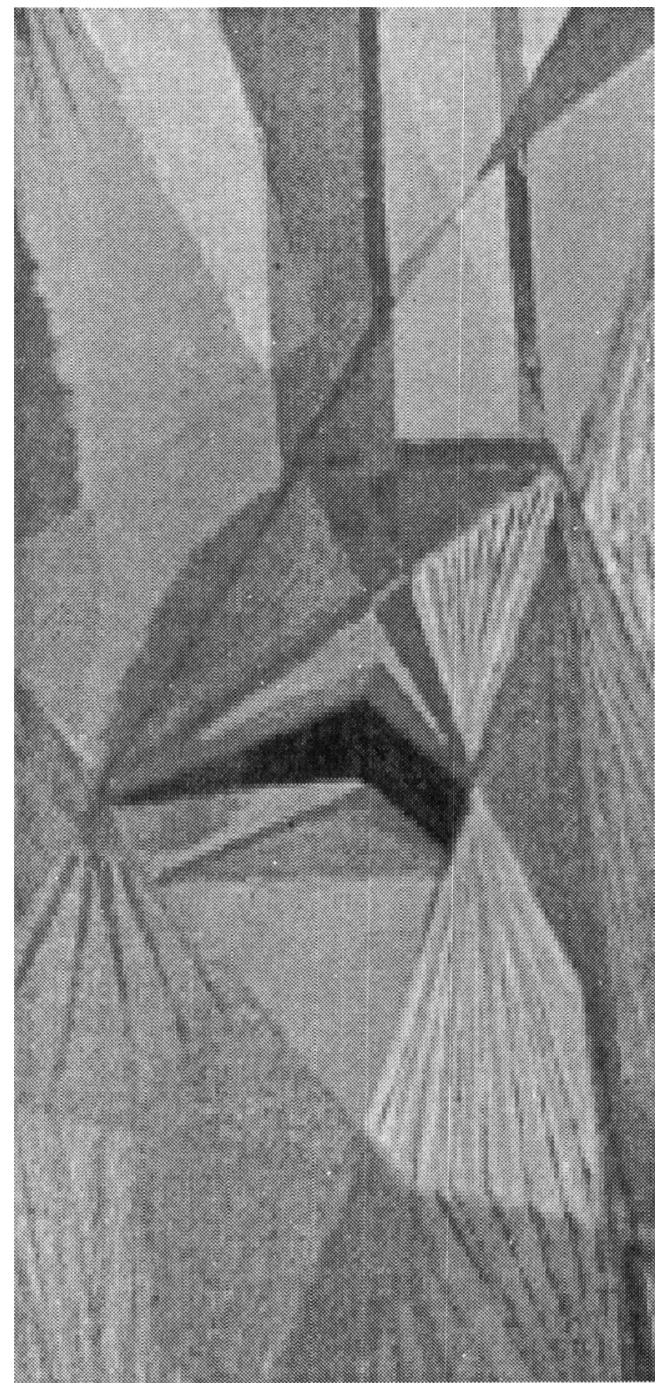

análise documental por parecer importante partir do conhecimento já produzido. Foram consideradas como fontes de informação as entidades: Programa Integrar PUC/CUT e UNITRABALHO. 


\section{Documentos selecionados}

Foram selecionados para documentos de análise aqueles que tratavam do emprego/desemprego, da qualificação/requalificação e da descrição do trabalhador a respeito dos assuntos anteriormente citados.Das fontes indicadas foram utilizadas os seguintes documentos: 1. Caracterização psicossociológica do metalúrgico desempregado, 2- Análise da situação do emprego e desemprego no Estado de Săo Paulo e 3-Avaliação do plano de qualificação e requalificação profissional do Estado de São Paulo.Características gerais dos documentos selecionados:

\begin{tabular}{|c|c|}
\hline Titulo & Caracterizaçáo Psicossociológica do Metalurgico Desempregado \\
\hline Autor/Instituição & Luiza N. B. Alonso \\
\hline data & 17 de Março de 1997 \\
\hline Características Gerais & $\begin{array}{l}\text { Pesquisa realizada através do convênio PUC/CUT. A pesquisa } \\
\text { teve como objetivo caracterizar quem é o metalúrgico } \\
\text { desempregado, como é seu cotidiano, quais suas estratégias } \\
\text { de sobrevivência, sua história de vida e como ele descreve } \\
\text { sua auto-imagem e suas expectativas de futuro. A coleta de } \\
\text { dados foi realizada por meio de entrevistas individuais com } \\
39 \text { sujeitos. Pesquisa não publicada, contendo } 109 \text { páginas, } \\
\text { podendo ser encontrada Programa Integrar PUC/CUT }\end{array}$ \\
\hline
\end{tabular}

\section{Documento 2}

\begin{tabular}{|c|c|}
\hline Titulo & $\begin{array}{l}\text { Análise da Situaçáo do Emprego e Desemprego no Estado } \\
\text { de Sáo Paulo }\end{array}$ \\
\hline Autor/Instituição & $\begin{array}{l}\text { FIPE/USP (Fundação Instituto de Pesquisa Econômica da } \\
\text { Universidade de São Paulo) e Unitrabalho }\end{array}$ \\
\hline data & Janeiro de 1997 \\
\hline Características Gerais & $\begin{array}{l}\text { Teve como objetivo avaliar a evolução do emprego e as } \\
\text { características do desemprego, no mercado de trabalho do } \\
\text { Estado de São Paulo na última década. O trabalho foi } \\
\text { estruturado em três partes: I- Crescimento econômico e } \\
\text { geração de emprego: São Paulo nos anos } 90 \text {. II- Desemprego: } \\
\text { Características e políticas públicas. III- Evolução do mercado } \\
\text { de trabalho em Campinas. No presente trabalho foram } \\
\text { utilizadas as duas primeiras partes. Pesquisa não publicada, } \\
\text { contendo } 139 \text { páginas, podendo ser encontrada na Fundação } \\
\text { Unitrabalho. }\end{array}$ \\
\hline
\end{tabular}

\section{Documento 3}

\begin{tabular}{|l}
\hline Titulo \\
$\begin{array}{l}\text { Avaliação do Plano de qualificação e requalificaçáo } \\
\text { profissional do Estado de São Paulo Instituição }\end{array}$ \\
Fundação Unitrabalho \\
27 de laneiro de 1997 \\
Características gerais \\
Pesquisa realizada através de convênio com a SERT (Secretaria \\
do Emprego e Relações do Trabalho do Estado de São Paulo). \\
Esta pesquisa teve como objetivo avaliar os cursos de formação \\
profissional do ponto de vista dos alunos e das entidades contratadas \\
para ministrar tais cursos. Foram avaliados os recursos pedagógicos, a \\
metodologia de ensino, a motivação da instituição em oferecer os cursos \\
e a dos alunos para procurar os mesmos, a evasão e o perfil do aluno. \\
Pesquisa contendo 138 páginas, não publicada, podendo ser \\
encontrada na Fundação Unitrabalho.
\end{tabular}




\section{Procedimento}

Tendo estes documentos em mãos, procedeu-se da seguinte forma:

\section{1 - Preparação dos Documentos}

1.1- Tirou-se uma cópia xerox dos documentos 1,2 e 3; do documento 3 foi tirada também uma cópia em disquete do banco de dados relativos à cidade de Sáo Paulo.

1.2- Com o obietivo de familiarizar-se com o conteúdo dos mesmos, foi realizada uma leitura geral.

1.3- Feito isto, realizou-se uma releitura mais cuidadosa e dirigida, tendo em vista a questão que dirige este trabalho.

\section{2 - Seleção e Registro das Informações}

A partir dos documentos foram selecionados e registrados as seguintes informaçóes:

Documento 1:

a) A autora do documento realizou entrevistas, transcrevendo frases das mesmas sem identificar os autores, agrupando-as em temas de análise. Pelo conteúdo das frases, pode-se notar que as mesmas pertenciam a diferentes sujeitos. Entretanto, como não foi possivel identificar a qual sujeito pertencia cada frase, a frase passou a ser a unidade de análise.

Estas frases foram objeto de análise no presente trabalho, para isto foram reagrupadas em categorias de análise (conforme Anexo1). b) A seguir, construiu-se duas folthas de registro, uma com o sub-tema, Causas do desemprego e a outra com o sub-tema, descrição do trabalhador em relação a percepção do outro.

\section{Documento 2:}

a) Foram utilizados os dados que apontam as características do emprego e desemprego na cidade de São Paulo.

b) Nenhuma folha especial de registro foi necessária.

c) Foram selecionados os dados referentes a taxa anual de desemprego, segundo IBGE e SEADE, distribuiçāo dos empregos por setores de atividade e evolução do emprego por grau de escolaridade.

\section{Documento 3:}

a) Foram utilizados os dados brutos relativos à cidade de São Paulo, através de uma cópia em disquete do banco de dados, excluindo da análise os alunos que ainda nào haviam ingressado no mercado de trabalho. Os dados foram categorizados segundo o tema: Perfil do trabalhador.

b) Através de um programa de computador, retirou-se do banco de dados as seguintes informações: grau de escolaridade do trabalhador aluno, idade em que começou a trabathar e objetivo do trabalhador aluno ao fazer o curso.

c) Realizou-se um cruzamento entre os dados dos trabalhadores empregados e desempregado, na época do curso, agrupando-os em categorias de análise.

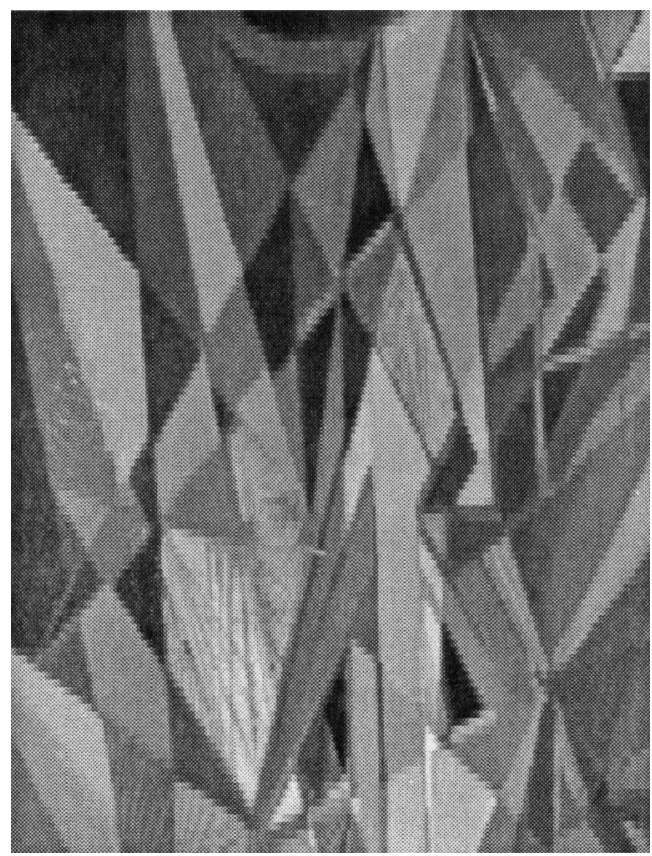

\section{3- Procedimento de Análise}

3.1 - Selecionou-se, então, três grandes temas para a análise. São eles: a) Características gerais do emprego e desemprego; b) Perfil do aluno trabalhador; c) Características gerais do emprego e desemprego segundo o trabalhador.

3.2 - Os temas de análise foram divididos em sub-temas e estes agrupados em categorias, da seguinte forma: 
Tema: Caracterização do Emprego e Desemprego

Sub-tema: Setores de Atividade no Volume de Emprego

\section{Categorias:}
a) Indústria
b) construção civil
c) comércio
d) serviços
e) agropecuária
c) outros

\section{Sub-tema: Grau de escolaridade}

\section{Categorias:}

a) menos de 5 anos de escolaridade

c) de 9 a 11 anos de escolaridade

b) de 5 a 8 anos de escolaridade

d) mais de 11 anos de escolaridade

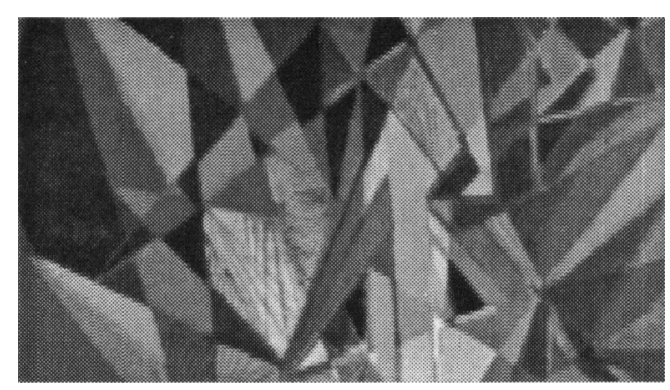

Tema: Perfil do trabalhador aluno

Sub-tema: Grau de escolaridade

\section{Categorias:}
a) 1-4. série incompleta
e) 1-3*. série $2^{\circ}$. grau incompleta
b) $1-4^{2}$. série completa
f) 1-3. série $2^{\circ}$. grau completa
c) 5-8. série incompleta
g) $3^{\circ}$. grau incompleto
d) 5-8a série completa
$3^{\circ}$. grau completo

\section{Sub-tema: Idade em que começou a trabalhar}

\section{Categorias:}

Sub-tema: Objetivo do trabalhador aluno desempregado ao fazer o curso

\section{Categorias:}
a) melhorar a qualificação
b) arrumar emprego
c) outros

Sub-tema: Objetivo do aluno trabalhador aluno empregado ao fazer o curso

\section{Categorias:}
a) mudar de emprego
b) alcançar um melhor cargo
c) outros

Tema: Características gerais do emprego e desemprego, segundo o trabalhador

\section{Sub-tema: Causas do desemprego \\ Categorias:}
a) estudo insuficiente
c) características pessoais
b) mudanças tecnológicas
d) maldade dos empresários

\section{Sub-tema: Descrição do trabalhador em relação à percepção do outro}

\section{Categorias:}
a) vergonha
b) exclusão
c) desamparo

\section{Resultados e Discussão}

Os resultados e discussão serão apresentados segundo os três temas de análise:
1- Características do emprego e do desemprego
2- Perfil do trabalhador aluno
3- Características do emprego e do desemprego, segundo o trabalhador 


\section{1 - Características do Emprego e Desemprego}

Tabela 1. Taxa média anual de desemprego, segundo IBGE e SEADE

\begin{tabular}{|c|c|c|}
\hline Ano & IBCE & SLAIIL \\
\hline 1986 & 3,3 & 8,2 \\
\hline 1987 & 3,8 & 9,1 \\
\hline 1988 & 4,0 & 8,9 \\
\hline 1989 & 3,4 & 7,0 \\
\hline 1990 & 4,8 & 9,4 \\
\hline 1991 & 5,5 & 10,2 \\
\hline 1992 & 6,4 & 14,6 \\
\hline 1993 & 5,7 & 13,5 \\
\hline 1994 & 5,0 & 13,2 \\
\hline 1995 & 5,2 & 13,7 \\
\hline 1996 & 5,3 & 14,5 \\
\hline
\end{tabular}

Fonte: FIPE/USP (1997)

Os autores do documento, ao analisarem a evolução da taxa de desemprego, chamam a atençāo para a diferença entre os índices de desemprego medidos pelo IBCE e pelo SEADE. Segundo esses autores, essa diferença ocorre em funçăo das diferenças metodológicas, na coleta de dados, que cada instituição realiza. Enquanto o IBGE considera desempregado apenas aqueles sem qualquer ocupação que procuraram emprego na última semana, o SEADE toma como referência o período de um mês.
O reflexo desta diferença é que, de acordo com cada índice, a análise da situação do desemprego pode ser extremamente favorável ou desfavorável. O desemprego no Brasil, comparado ao de outros países, estará entre os mais baixos do mundo se os índices do governo federal (IBGE) forem considerados os únicos válidos; porém, se os índices do SEADE é que forem considerados, o desemprego no país estará entre os mais altos do mundo, sendo maior apenas na Espanha.

De qualquer maneira, independente do instituto que se tome por base, há concordância quanto à evolução do desemprego na última década. De acordo com o IBGE, a taxa de desemprego teria passado de $3,3 \%$, em 1986 , para $5,3 \%$, em 96 (evolução de $60 \%$ no índice), de acordo com o SEADE, a taxa de desemprego teria passado de $8,2 \%$, em 1986 , para $14,5 \%$, em 1996 (evoluçāo de $76 \%$ no índice). A evoluçăo do índice corresponde ao aumento no número de desempregados.

Podemos assim, verificar que o desemprego é um problema cada vez mais sério pois vem aumentando na última década em velocidade crescente, cabe então verificar se o desemprego vem aumentando em todos os setores da economia, ou se é localizado, cabe também pesquisar para onde vai o trabalhador desempregado.

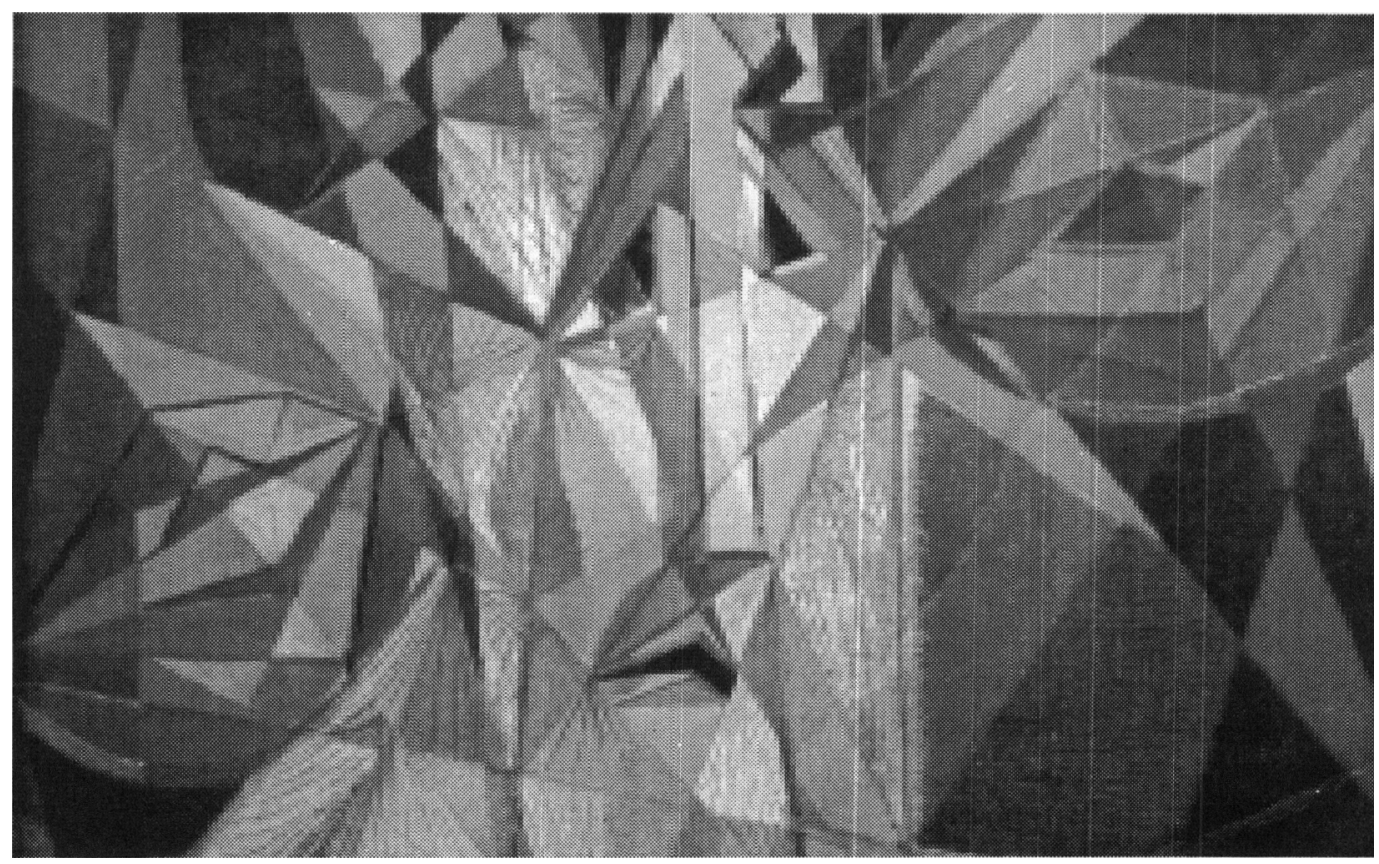


Tabela 2. Distribuição dos Empregos por Setores de Atividade

\begin{tabular}{|l|l|l|l|l|l|l|}
\hline ano & Indústria & const.civil & Comércio & Serviços & Agrop. & Outros \\
\hline 1986 & $37,46 \%$ & $6,42 \%$ & $12,33 \%$ & $43,16 \%$ & $0,08 \%$ & $0,54 \%$ \\
1993 & $19,99 \%$ & $3,51 \%$ & $17,54 \%$ & $30,15 \%$ & $8,30 \%$ & $20,32 \%$
\end{tabular}

Fonte: FIPE/USP (1997)

Como podemos observar está havendo uma redistribuiçăo do emprego por setores de atividades. Considerando os setores tradicionais de atividade (indústria, construção civil, comércio, serviços e agropecuária), notamos que a indústria, construção civil e serviços vêm perdendo participação na oferta de empregos, com exceção da atividade comercial e da agropecuária; merece destaque a diminuição de $37,4 \%$ para $19,99 \%$ na participação da indústria no total de empregos. No mesmo período, o número de pessoas que exercem alguma atividade em outros setores, que não aqueles tradicionais da economia, aumentou substancialmente, de $0,54 \%$ para $20,32 \%$, indicando uma precarizaçāo do emprego. Esta redistribuição pode estar indicando que o trabalhador demitido, quando não consegue recolocar-se no mercado de trabalho, busca alternativas de ocupação na chamada economia informal, setor que se caracteriza pela ausência ou precariedade dos contratos, falta de garantias sociais e ocupação temporária.

Um exemplo disso é o que ocorre todas as madrugadas no Largo Treze de Maio em São Paulo, onde centenas de trabalhadores aglomeram-se a espera de empreiteiros que os contratam para tarefa de um dia; estes intermediários escolhem os mais aptos para serviços, em geral degradantes e intensivos. Ainda assim, há disputa entre os trabalhadores por năo terem outra alternativa; nessa disputa os mais velhos e os mais fracos são descartados. Os escolhidos entram em peruas sem saberem aonde vāo, nem para o que, exatamente, foram contratados; ao anoitecer, exaustos são deixados novamente na praça.

A diminuiçăo do emprego na indústria reflete, como salientaram Mattoso (1996) e Antunes (1997) a busca deste setor, por maior produtividade, isto é, mais produto por hora trabalhada, levando a indústria a adotar mudanças na divisão do trabalho dentro da empresa, diminuição do ciclo de produçăo, consolidação da tecnologia da computaçāo e da informática. Essas mudanças têm como decorrência o desaparecimento cada vez maior de postos de trabalho.

O discurso ideológico -que conforme Chauí (1982), caracteriza-se por não dizer tudo e apenas mostrar um recorte da realidadedefende que as vagas fechadas numa empresa serăo reabertas, num hipotético momento em que, graças ao ganho de produtividade, a empresa começar a ganhar mercado de outras; entretanto, mesmo que isso ocorra haverá, entāo, trabalhadores demitidos nas empresas que perderem participaçāo no mercado, não havendo ganho de postos de trabalho para a classe trabalhadora como um todo.

Assim, os postos de trabalho fechados na indústria desaparecerāo, com poucas chances de serem absorvidos por outros setores. Segundo Forrester (1997) :

"Um desempregado, hoje, nāo é mais objeto de uma marginalização provisória, ocasional, que atinge apenas alguns setores; agora, ele está às voltas com uma implosāo geral, com um fenômeno comparável a tempestade, ciclone e tornados, que năo visam ninguém em particular, mas aos quais ninguém pode resistir" (p.11).

Portanto, a busca incessante por produtividade tem como conseqüência o fechamento de postos de trabalho e não a criação de novos emprego, já que para o mercado de trabalho como um todo o resultado será sempre negativo, indicando que o desemprego não é episódico, mas sim estrutural.

Segundo o discurso ideológico, a melhoria na produtividade exige trabalhadores cada vez mais qualificados, vinculando o desemprego à escolaridade deficiente. Desta forma é necessário verificar se há esta relaçăo. 


\section{Tabela 3. Evolução do Desemprego por Grau de Escolaridade}

\begin{tabular}{|c|c|c|c|}
\hline Escolaridade & 1986 & 1995 & Variação \% \\
\hline Menos de 5 anos & 2,7 & 3,6 & 33,3 \\
\hline 5 a 8 anos & 5,3 & 6,6 & 24,5 \\
\hline 9a 11 anos & 4,3 & 5,7 & 32,6 \\
\hline Mais de 11 anos & 2,1 & 2,3 & 9,5 \\
\hline
\end{tabular}

O desemprego cresce em todas as faixas de escolaridade. A variação no aumento do desemprego é praticamente a mesma tanto para os que tem menos de 5 anos de escolaridade $(33,3 \%)$ quanto para os que tem de 9 a 11 anos de escolaridade $(32,6 \%)$. Nos extremos da tabela, menor escolaridade e maior escolaridade, são encontrados os menores índices de desemprego, embora também crescente, mostrando que não há relação entre maior escolaridade e garantia de emprego, e menor escolaridade e menor chance de emprego.

Entretanto, o discurso ideológico prega que o desemprego é causado pela falta de qualificaçāo (formal ou técnica) do trabalhador. O trabalhador busca então cursos de qualificação como forma suprir as deficiências que the săo atribuidas.

\section{2 - Perfil do Trabalhador Aluno}

Entre os trabalhadores que procuraram o plano de qualificação $74,1 \%$ encontram-se desempregados e $25,9 \%$ empregados (fonte: Unitrabalho, 1997). Esses índices, isto é, a presença de um maior número de desempregados (quase três vezes mais) podem ser um indicativo de que o trabalhador aluno tem esperança de que melhorando sua qualificação possa encontrar emprego.

\section{Tabela 4. Nível de Escolaridade do Trabalhador Aluno}

\begin{tabular}{|c|c|c|}
\hline Série cursada & desempregado & empregado \\
\hline 1-4. série incompleta & 3,90 & 5,70 \\
\hline 1-4. série completa & 6,70 & 3,40 \\
\hline 5-8. série incompleta & 25,60 & 19,00 \\
\hline 5-8. série completa & 15,40 & 8,00 \\
\hline 1-3. série 2 . grau incompleta & 16,60 & 22,70 \\
\hline 1-3. série 2 . grau completa & 24,80 & 23,90 \\
\hline 3. grau incompleto & 3,10 & 8,00 \\
\hline 3. grau completo & 3,90 & 10,2 \\
\hline
\end{tabular}

Entre os trabalhadores que procuram o curso de qualificação, independente de estarem ou nāo empregados, a maioria tem escolaridade média (de 5 a 11 anos de escolaridade), que é justamente a faixa com maior incidência de desempregados, conforme dados da Tabela 3.

\section{Tabela 5. Idade em Que o Trabalhador Aluno Começou a Trabalhar}

\begin{tabular}{|c|c|c|}
\hline Idade & desempregado & empregado \\
\hline menos de 14 anos & 37,50 & 34,83 \\
\hline 14 a 17 anos & 44,36 & 42,70 \\
\hline 18 a 21 anos & 16,53 & 19,10 \\
\hline mais de 21 anos & 1,61 & 3,37 \\
\hline
\end{tabular}


Os dados da Tabela 5 mostram que mais de $70 \%$ dos alunos trabalhadores ingressaram no mercado de trabalho antes do 17 anos e que para mais de $30 \%$ o ingresso ao mercado de trabalho foi ainda mais precoce, antes do 14 anos.

Pode-se observar que até a idade de ingresso no mercado de trabalho a maioria dos alunos teve tempo de completar apenas a escolaridade média (de 5 a 11 anos), o que novamente nos remete à Tabela 3 , pois é exatamente nesta faixa que se encontra a maioria dos desempregados.

Tabela 6. Objetivo do trabalhador aluno desempregado ao fazer o curso de qualíficação

\begin{tabular}{|lr}
\hline objetivo & $\%$ de respostas \\
\hline melhorar a qualificação & $56,2 \%$ \\
\hline arrumar emprego & $27,3 \%$ \\
\hline outros & $16,5 \%$
\end{tabular}

Fonte: Unitrabalho (1997)

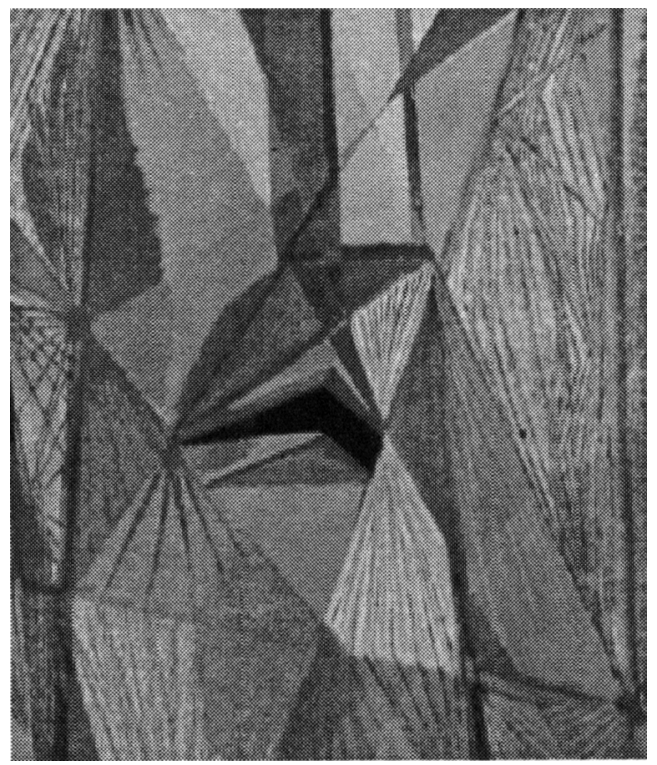

Tabela 7. Objetivo do trabalhador aluno empregado ao fazer o curso

\begin{tabular}{lr}
\hline objetivo & $\%$ de respostas \\
\hline mudar de emprego & $53,9 \%$ \\
alcancar um melhor cargo & $19,7 \%$ \\
\hline $\begin{array}{l}\text { outros } \\
\text { Fonte: Unitrabalho (1997) } \\
\text { ronte: Unutrabaimo (7997) }\end{array}$ & $16,4 \%$
\end{tabular}

Conforme a Tabela 6 entre os desempregados mais de $70 \%$ tem como objetivo melhorar a qualificaçăo e arrumar emprego. Mesmo entre aqueles que estāo empregados, (Tabela 7) mais de $70 \%$ esperam que os cursos de qualificaçăo contribuam para uma promoçāo dentro da mesma empresa ou para conseguirem um emprego melhor.

Esses dados são um indicativo de que o trabalhador tem esperança de que melhorando sua qualificação (completando o ensino formal ou adquirindo conceitos básicos de profissōes técnicas) possa tornarse mais atraente para o mercado de trabatho, aumentando suas chances de conseguir emprego.

Entretanto, Pochmann (1997) salienta: " Em 1996 cerca de 1,2 milhões de pessoas completou algum curso de qualificação profissional pelo plano Nacional de formação do Ministério do Trabalho, no mesmo ano houve profunda redução nas ocupações na indústria que, em tese, exige maior qualificaçāo" (p.36).

\section{3 - Características gerais do emprego e desemprego, segundo o trabalhador aluno}

A maioria absoluta dos trabalhadores alunos (84,5\% entre os desempregados e $89,7 \%$ dos empregados) considera que a causa do desemprego é a falta de qualificaçâo dos próprios trabalhadores (fonte: Unitrabalho, 1997)

Tabela 8. Causas do desemprego, segundo o trabalhador aluno

\begin{tabular}{|c|c|}
\hline causa do desemprego & número de frases \\
\hline estudo insuficiente & 14 \\
\hline mudanças tecnológicas & 6 \\
\hline características pessoais & 4 \\
\hline maldade dos empresários & 2 \\
\hline total & 26 \\
\hline
\end{tabular}

As frases aqui agrupadas em categorias, não seguem o mesmo critério da autora do documento, pois a mesma não utilizou-se de categorias, valeu-se dos seguintes temas de análise: O cotidiano, estratégias de vida, histórico da vida, auto-imagem, sonhos e expectativas e valores. 
Quando o trabalhador descreve as causas do seu próprio desemprego, na maioria das vezes atribui a si a responsabilidade pela situação, considera-se com estudo insuficiente (formal ou técnico), despreparado para as mudanças tecnológicas, velho (43 anos) ou mesmo tímido.

Outros ainda lamentam terem sido excluídos da escola em função do trabalho, e agora são excluídos do mercado de trabalho por nāo terem estudado.

"Por causa da fábrica eu não tinha horário para estudar, daí fui mandado embora porque não tinha o primeiro grau"

As descrições vêm, em geral, acompanhadas de sentimento de culpa e arrependimento, assim o desemprego é vivido de forma bastante crítica pelo trabalhador.

"Eu me sinto arrependido de nāo ter estudado" "Me sinto culpado arrependido por ter parado de estudar"

Segundo Forrester (1997), essa crítica que eles mesmos se fazem e que se baseiam em percepçōes defasadas da conjuntura é ainda mais absurdas nos dias atuais.

Os trabalhadores procuram empregos que não existem, culpam-se por nāo estarem preparados para as mudanças tecnológicas sem perceberem que essas mudanças tecnológicas estão entre as causas do desemprego.

"Hoje em dia um torneiro mecânico está precisando ter o segundo grau para poder operar os tornos novos"

Essa autodescriçāo da situação de desemprego pode ser considerada como autoconhecimento (uma descrição) com lacunas, pois o trabalhador sabe descrever seu comportamento, mas não as variáveis das quais ele é função.

Quando o trabalhador atribui a si mesmo a culpa, essa descrição pode estar sob o controle do discurso ideológico (fragmentário, lacunar e que não diz tudo), discurso esse, que pode aqui ser entendido, como regra, isto é, um estímulo verbal que descreve uma contingência, embora a descriçăoo da contingência nunca seja completa ou exata.
Tabela 9. Como o Trabalhador Sem Emprego Descreve Seus Estados Internos

\begin{tabular}{lc} 
Descrição & número de frases \\
vergonha & 08 \\
exclusão & 06 \\
desamparo & 02 \\
total & 16 \\
\hline
\end{tabular}

Fonte: Programa Integrar PUC/CUT (1997)

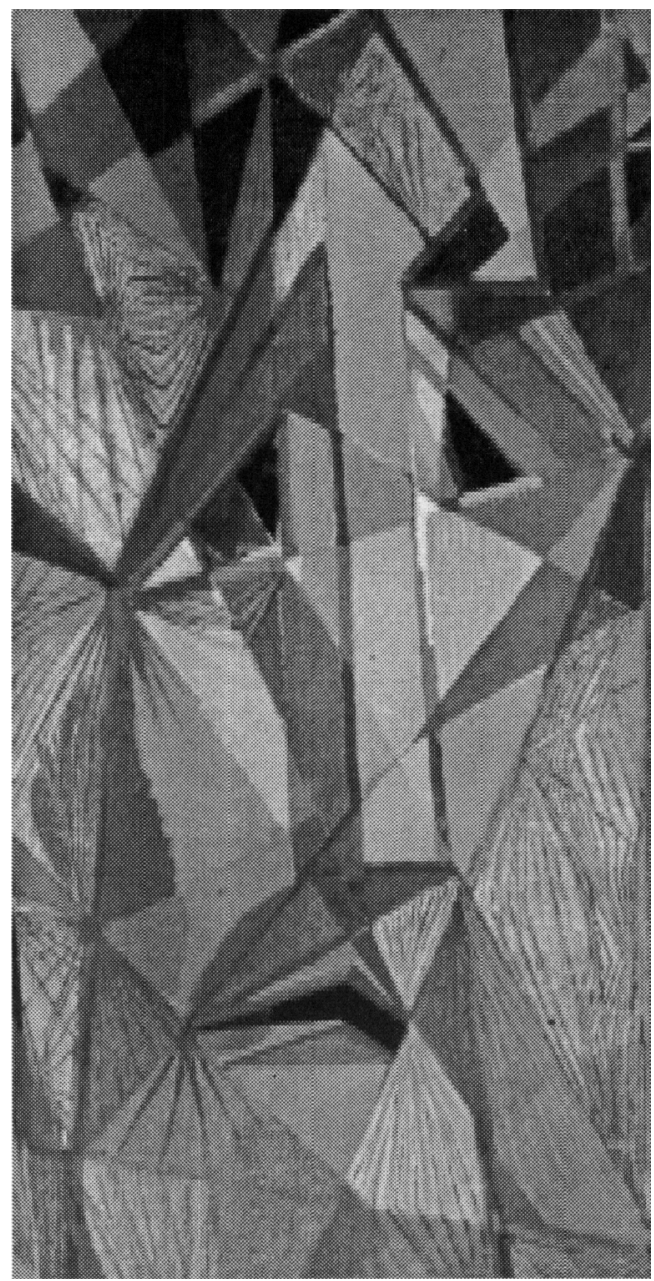

As frases foram agrupadas em categorias (Tabela 9), que foram utilizadas por parecer serem as que melhor descrevem os estados internos descritos pelos trabalhadores.

O termo vergonha foi aqui utilizado no seu sentido de constrangimento resultante da idéia ou do receio de desonra; exclusão para designar o sentimento de estar excluído da sociedade eo desamparo como oestado de inaçāo. 
Um dos principais estados internos que o trabalhador, diante do desemprego, descreve (Tabela 9), é o sentimento de vergonha, sentimento esse que tem como conseqüência o sofrimento, em outras palavras:

"Tudo isso -que não tem nada de inocenteos leva a essa vergonha, a esse sentimento de ser indigno, que conduz a todas as submissöes. $A$ abjeção desencoraja qualquer outra reação de sua parte que não seja uma resignação mortificada.

Pois não há nada que enfraqueça nem que paralise mais que a vergonha. Ela altera na raiz, dejxa sem meios, permite toda espécie

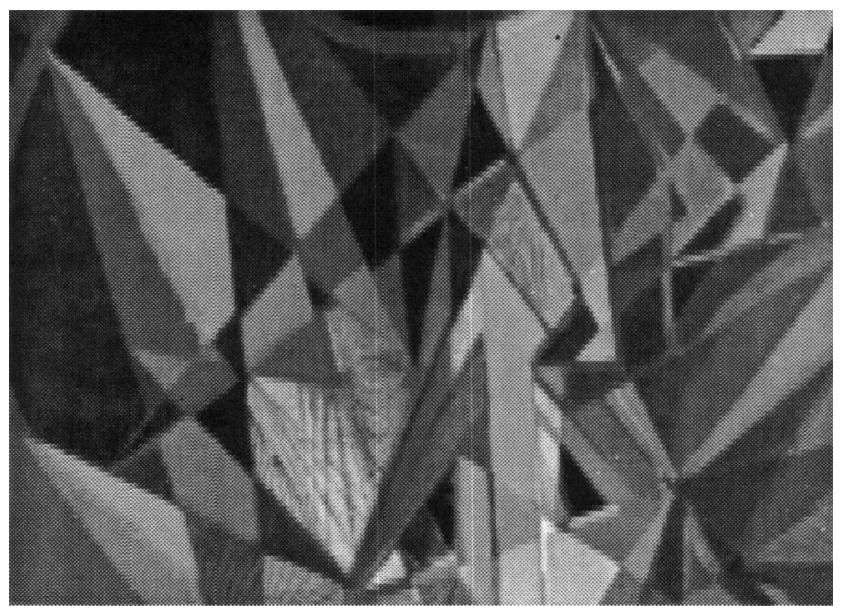

de influência, transforma em vítima aqueles que sofrem, daí o interesse do poder em recorrer a ela e a impô-la; ela permite fazer a lei sem encontrar oposiçāo, e transgredi-la sem temor de qualquer protesto" (Forrester, 1997 p.12).

Isto fica claro em frases do tipo: "A gente se sente pior, porque é no meio de várias pessoas você é dispensado, você se sente diferente, se sente menor do que aquelas pessoas e mesmo em casa você vê os vizinhos, todo mundo trabalhando, comprando e tal e você dentro de casa desempregado."

A exclusão é outro sentimento bastante descrito pelo trabalhador desempregado e revela sentimento em relação ao seu cotidiano; ele năo mais se sente parte da sociedade, é como se o fato de não ter emprego tirasse o seu direito ao convívio social, isto é, esta exclusão é descrita como vinda do outro.
"O sistema age desta forma, se você está trabalhando, você é bom, se não os amigos passam por você e se escondem, nāo te chamam para lugar nenhum, atravessam até a rua."

Estas descriçōes do trabalhador (Anexo 1), indicam que ele percebe-se reprovado pelo outro. A percepção pode estar sob controle do modo como ele se vê, através da interação social. A crença em que é o responsável pelo desemprego, por não ter estudado, aumenta o sofrimento.

"Ao drama das identidades precárias ou anuladas. $O$ mais vergonhoso dos sentimentos: a vergonha. Porque cada um entăo se crê (é encorajado a crer-se) dono falido de seu próprio destino, quando não passou de um número colocado pelo acaso numa estatística.

Não é o desemprego em si que é nefasto, mas o sofrimento que o gera..." (Forrester, 1997, p.10).

Mais de $80 \%$ dos trabalhadores consideram que a falta de qualificação é a causa do desemprego (Fonte: Unitrabalho,1997). Entretanto, segundo a mesma fonte, quando perguntado se mesmo estudando é difícil conseguir emprego, $73 \%$ dos desempregados e $66,7 \%$ dos empregados, afirmam que sim. Este conflito pode estar ocorrendo pelo fato do trabalhador não estar sob o controle do estímulo presente, e sim da regra, quando afirma que o desemprego é por falta de qualificação do trabalhador, já quando afirma que mesmo estudando é difícil conseguir emprego pode estar sob controle de estímulo presente, isto é, da sua realidade imediata que o expōe diretamente às contingências.

\section{Conclusāo}

Partindo do problema inicial, que é verificar como o trabalhador descreve sua percepção sobre a reestruturação produtiva e a qualificação/requalificaçāo, a análise dos dados mostra que o trabalhador tem pouca clareza do que é a reestruturação produtiva, isto é, não sabe descrever as variáveis envolvidas no atual modelo de produçāo e, descreve o desemprego como decorrência da falta de escolaridade (formal ou técnica) do trabalhador. 
Pode-se, então, dizer que o trabalhador não possui um repertório discriminativo das variáveis envolvidas neste modelo de produção, que se caracteriza pela busca de maior produtividade, através da consolidação de novas tecnologias, redução do ciclo de produção, polivatência do trabathador e intensificação do ritmo de trabalho, medidas essas que tem como decorrência o desemprego.

O nível de aprendizado do trabalhador năo é a causa do seu desemprego. O nível de aprendizado do trabalhador é utilizado ideologicamente para legitimar a condição de cada um.

Como nos alerta Bravernann, mesmo que todos os trabalhadores fossem qualificados, ainda assim não haveria lugar para todos, entăo, o discurso ideológico encontraria outra fatsa razão para justificar a exclusão.

Esse fato do trabalhador descrever o desemprego como decorrência de deficiências pessoais, provoca sofrimento porque ele passa a procurar em sua história de vida as causas que o levaram ao desemprego. Resposta dada de antemão pela comunidade verbal.

A comunidade verbal vai modelando o comportamento do trabalhador reforçando diferencialmente suas respostas, através de aprovação ou reprovação.

A comunidade reforça com aprovação quando o trabalhador busca em sua própria história de vida deficiências que justificam sua condição, assim, mantém este comportamento de responsabilizar-se. Por outro lado, o comportamento de procurar no ambiente causas para o desemprego, questionando a forma como se dāo as relaçỏes de produção, é punido, às vezes a punição ocorre de maneira não tão explícita, sendo chamado de retrógrado, ingênuo, desinformado, que não sabe que o conflito entre capital e trabalho está superado.

O comportamento de auto descriçăo vai sendo socialmente construído, porque para a sociedade é vantajoso que os seus membros nāo questionem a ordem estabelecida. Assim, a sociedade exime-se de qualquer culpa.

Em outras palavras:
"Julgam-se com o othar daqueles que os julgam, othar esse que adotam, que os vê como culpados, e que os faz, em seguida, perguntar que incapacidade, que aptidão para o fracasso, que má vontade, que erros puderam levá-los a essa situaçäo" (Forrester, 1997, p.121).

Portanto, o desemprego traz não só o sofrimento da insegurança da sobrevivência, mas também a vergonha de estar desempregado. Assim, quando se fala de reestruturação produtiva, qualificação e requalificação, está se falando, acima de tudo, de sofrimento humano e, desta forma, de um problema de todas as áreas do saber e, em especial da psicologia que deveria

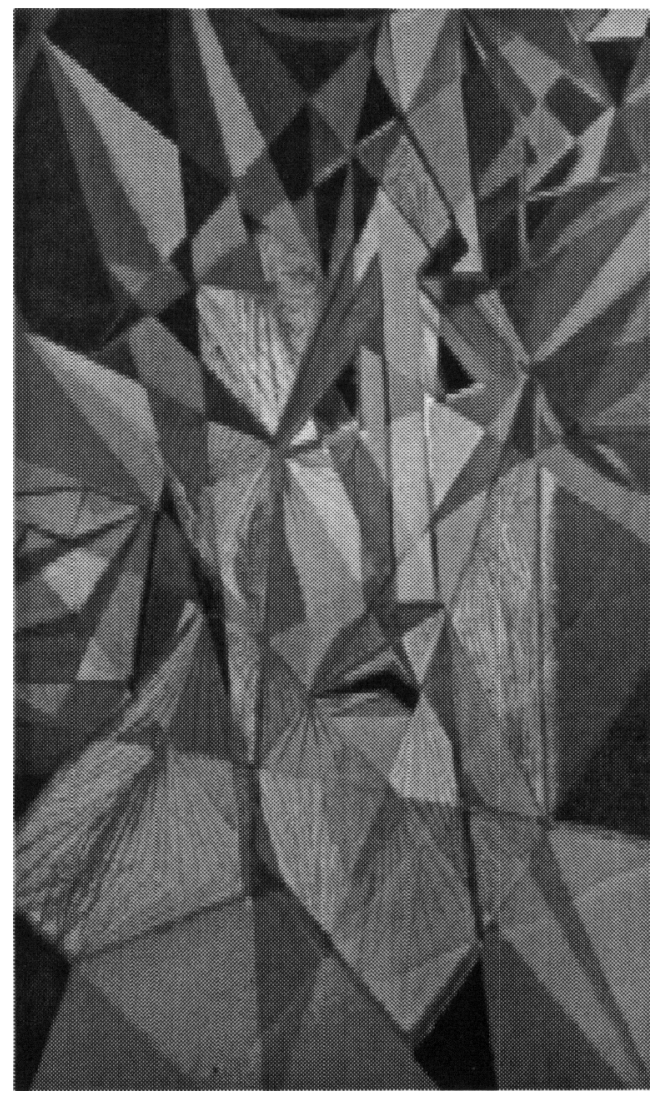

tratar da qualidade de vida. E está aqui a relevância deste trabalho, a de refletir a questão do desemprego e a sua repercussāo na qualidade de vida do trabalhador.

À Psicologia cabe não só observar e avaliar as contingências que estăo determinando a consciência parcial dos trabalhadores, mas, acima de tudo, atuar no ambiente de forma 
a ampliar a consciência do trabalhador para que ele possa ter controle de seu comportamento, afinal, como coloca Skinner:

"Ampliar a consciência que a pessoa tem do mundo exterior é simplesmente pô-la sob um controle mais sensivel desse mundo, como fonte de estimulação. Marx e outros tentaram levar as pessoas a um nível mais elevado de consciência' colocando-as sob o controle de aspectos de seu ambiente" (Skinner, 1974, p.133)

O acesso dos trabalhadores às novas tecnologias é urgente e necessário, entretanto se os benefícios dessas conquistas não forem revertidos para os trabalhadores, através da diminuição da jornada de trabalho, por exemplo, a classe trabalhadora como um todo só tem a perder: os empregados cada vez mais intensamente explorados e os desempregados em número cada vez maior. Sem uma análise que leve em conta as contingências que estāo determinando a instabilidade no mundo do trabalho, sem a percepção de que as relações de produção e formas de divisâo do produto são estas, mas poderão ser outras, o trabalhador continuará sofrendo duas vezes: uma pela carência material cada vez maior e outra por colocarse como responsável pelo próprio sofrimento.

Como alerta Forrester (1997) "É a partir de uma ruptura com a esperteza das versōes apressadas, das percepçōes factícias, dos simulacros impostos, que será possível abordar aquilo em que estamos realmente implicados" (p.55).

O propósito deste trabalho foi, não apenas produzir conhecimento, ou simplesmente fornecer dados, mas principalmente dar um passo além do que já foi produzido, ou seja, articular pesquisas já realizadas de forma a produzir algo novo sob o enfoque da análise experimental do comportamento.

Da mesma forma, é importante colocar que este trabalho não abrange (e nem tem a pretensão de fazêt+lo) a totalidade da questão, há muito ainda a ser estudado.

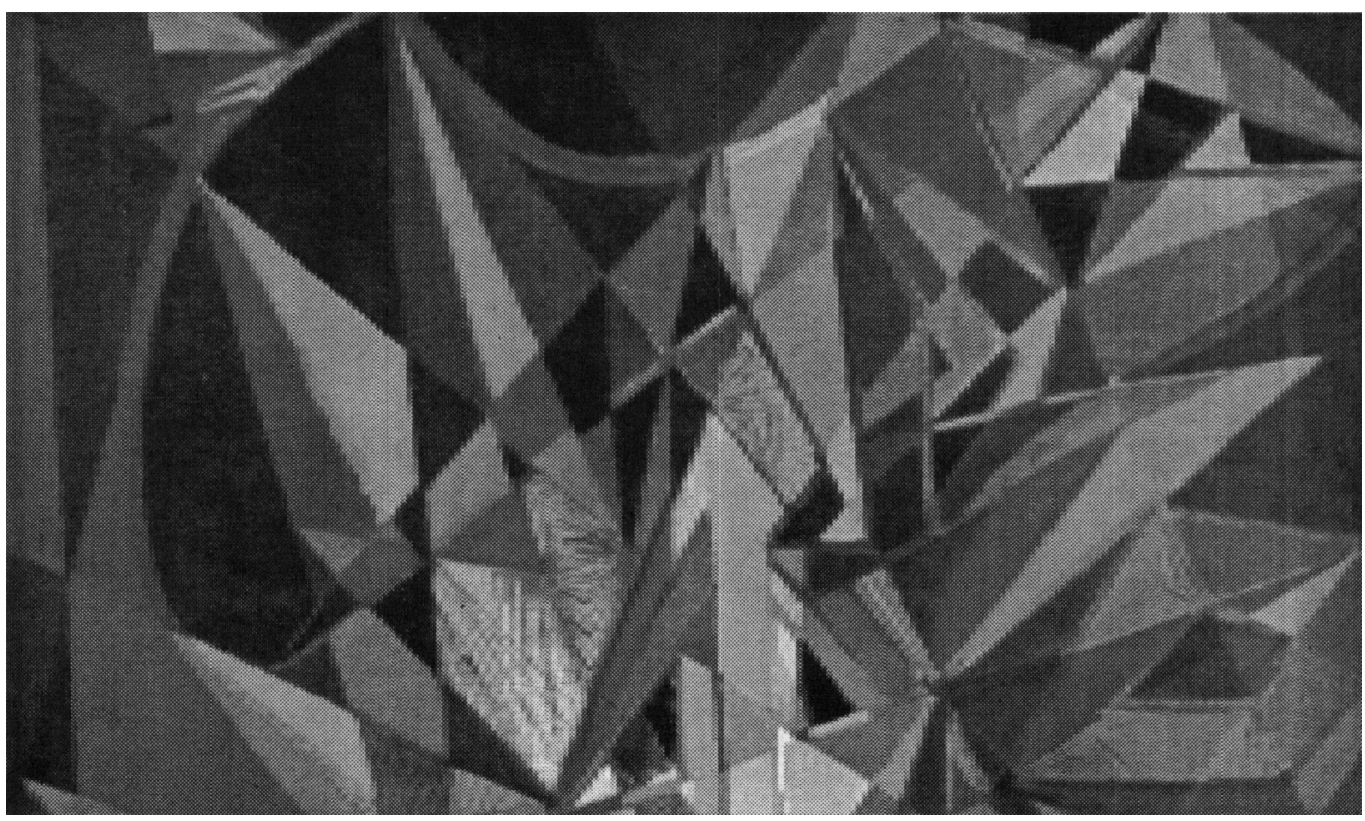


"Reestruturaçäo Produtiva, Qualificaçōo,

Requalificaçäo e Desemprego: Percepção e Sofrimento do Trabalhador"

Alonso, L. B.N. (1997) Caracterizaçāo Psicossociológica do Metalúrgico Desempregado. Săo Paulo

Antunes, R. (1997) Adeus as trabatho ? Ensaio sobre as metamorioses ea Centralidade do Mundo do Trabalho. 44. ed., São Paulo: Cortez.

Bottomore, I. (1983) Dicionário do Pensamento Marxista Rio de Janeiro: Jorge Zahar Editor t.tda.

Braverman, H. (1987) Trabalho e Capital Monopolista, , Rio de laneiro: Ed. Guanabara.

Casado, J. (06.07.1997) - Cultura da indíștria imade o Nordeste $\mathrm{O}$ Estado de Sâo Pauło, p.D-1)

Chauí, M. (1982) Cuftura e democracia, Sào Paulo: Moderna

Coriat, B. (1994) Pensar peio Avesso. , Rio de laneiro : Revan

Diesse (1996\} Inovaçōes Tecnológicas e Açāo Sindiçal Frente a Restruturação Produtiva do Estadio de Sáo Paulo.

Fotha de Sấo Paulo, (08.06.1997) Ranking do crescimento do PIB no Nordeste, cademo Brasil, p. 1-9)

Forrester, V (1997) O Honor Econônica Sáo Paulo: Editora Unesp
Gorz, A. 11987) Adeus ao Proletariado- Para além do Socialismo. 24. ed., Rio de Janeiro: Forense-Universitáría.

Kurz, R. (1993) O Colapso da Modenizaçâo, 3², ed., Săo Paulo: Paz e Terra.

Libâneo, J. (1986) Democratizaçâo da Escola Pública. A Pedagogia Crítica Social dos Conteúdos. Sāo Paulo: Loyola.

Mattoso, J. (1995) A Desordem do Trabalho ., Sâo Paulo: Scrita. Mattoso, J. (1996) Crise e Trabaliho no Brasit., Säo Paulo: Scrita.

Pochmann, M. (1997) Fermenta a desiguakdade, Carta Capital, $\mathbf{1}^{\circ}$. de outubro de 1997.

Stinner, B.F (1974) Sobre o Behaviorismo, Sào Paulo: Editora Cultrix.

Skinner, B.f. (1971) O Mito da liberdade, São Paulo: Summus editorial.

Tourinho, E. Z. (1995) O Autoconhecimento na Psicologia Comportamental de B. f. Skinner. Belém: Editora Universitấrią.

Unitrabatho (1997) Avaliaçāo do Plano de Qualificaçâo e Requalificaçăo Profissional do Estado de São Pauk. São Paulo

Zola, É. (1881) Cerminal. - Ediçào Brașileira (1979), Săo Pauk: Abril Cultura!
Referências bibliográficos 